\title{
NW-oriented features on both sides of the Atlantic Ocean: evidence for a Paleozoic collision that formed the Labrador-Biscay wrench fault zone?
}

\author{
J.P. Lefort ${ }^{1}$ and H.G. Miller ${ }^{2}$ \\ ${ }^{1}$ Geosciences-Rennes, Institut de Géologie, Campus de Rennes Beaulieu, 35042 Rennes \\ Cedex, France \\ ${ }^{2}$ Centre for Earth Resources Research, Department of Earth Sciences, Memorial University \\ of Newfoundland, St. John's, Newfoundland A1B 3X7, Canada
}

Date Received: July 15, 1999

Date Accepted: June 5, 2000

\begin{abstract}
Northwest-oriented features have been recognized for many years as fundamental components of the geology of the northwestern European continental shelves. Similarly oriented lineations and faults have been mapped throughout southwestern Britain, western France and across the English Channel. On land in Europe, similar trends are identified as far east as the Urals. Features of similar orientation, extending over a broad area on the North American continental shelf, have recently been identified from geophysical trends. On land in eastern Canada NW-SE faults have been mapped geologically and detected using geophysical and remote sensing data. A Mercator projection map on which the Atlantic Ocean has been restored to its pre-Mesozoic configuration, i.e. before the initiation of the most recent opening of the North Atlantic Ocean, shows that the features are similarly oriented.

Although some of the trends showing this direction may be younger, the geological data from both sides of the Atlantic Ocean suggest that the event that led to the formation of these NW-SE features post-dated the Variscan orogeny and may have been associated with the collision between Gondwana and Laurasia. The geometric patterns of the features interpreted as associated with the collision are consistent with patterns produced by a simple physical sandbox model of indentation with a rigid confinement to the west and a small lateral confinement to the east. This configuration is similar to that expected of Gondwana and Laurasia during the late Paleozoic. Faults considered younger than this collision may represent tectonic rejuvenations associated with the initiation of the opening of the North Atlantic Ocean.
\end{abstract}

L'orientation observée du nord-est vers le sud-est des formations rocheuses est reconnue depuis de nombreuses années comme une caractéristique géologique fondamentale des plateaux continentaux du nord-ouest de l'Europe. Des structures linéaires et des failles d'orientation similaires ont été répertoriées dans tout le sud-ouest de l'Angleterre, dans l'ouest de la France et à travers la Manche. Sur le continent européen, des tendances analogues ont pu être observées aussi loin à l'est que dans la chaîne de l'Oural. Ces caractéristiques orientées qui recouvrent une vaste région du plateau continental de l'Amérique du Nord ont récemment été observées à partir de tendances géophysiques. Dans l'Est canadien, des failles orientées NO-SE ont été portées sur des cartes géologiques et détectées à l'aide de données géophysiques et de télédétection. Ces caractéristiques observées ont été portées sur une carte à projection de Mercator où figure l'océan Atlantique dans sa configuration d'origine pendant l'ère pré-mésozoïque, soit avant que ne s'amorce l'ouverture la plus récente de l'Atlantique Nord. Ces caractéristiques reproduisent la même orientation lorsqu'elles sont portées ainsi sur la carte.

Bien que certaines des tendances qui signalent cette orientation semblent d'apparition plus récente, les données géologiques des deux côtés de l'Atlantique portent à croire que le phénomène qui a mené la création de ces linéations NOSE est survenu après l'orogenèse de varisque et peut être relié à l'hypercollision survenue entre la Gondwanie et la Laurasie. Les formes géométriques de ces linéations interprétées en relation avec la collision sont du même type que celles produites dans un modèle d'échancrure géologique dans un simple carré de sable, celles-ci présentant un confinement rigide à l'ouest et un petit confinement latéral à l'est. Il s'agit d'une configuration semblable à celle qui serait caractéristique de la Gondwanie et de la Laurasie. Les failles jugées plus récentes et issues de cette collision pourraient être attribuables à une régénération tectonique qui a accompagné le début de l'ouverture de l'Atlantique Nord.

Traduit par la rédaction

\section{INTRODUCTION}

Kay (1969) first suggested that the opening of the North Atlantic Ocean was controlled by a pre-existing basement weakness trending northwest-southeast between the Bay of Biscay and the Labrador Sea. Except for the reconstruction of Le Pichon et al. (1977) where the Bay of Biscay fault is shown but not really incorporated in the opening process, no subsequent attempt has been made to explain the data from both sides of the Atlantic Ocean. This situation may have been a consequence of the different levels of data and interpretations published. On the European side, considerable data existed and a number of interpretations have been published (e.g., Lefort 1973; 1975). On the North American 
side, the data existed, but interpretation of the presence of the $\mathrm{NW}$-oriented features (azimuths between $310^{\circ}$ and $320^{\circ}$ ) on land (Miller 1990; Williams et al. 1995) and on the Grand Banks of Newfoundland (Welsink et al. 1988; Miller 1990; Miller and Singh 1995) were presented more recently. On the European side, the continental shelves are narrow and contain many NW-trending faults. The North American continental margin is wider and was apparently unaffected by such faults. These apparent differences led to speculation that the inferred asymmetry of faulting controlled the opening of the North Atlantic Ocean (Lefort 1973). New data (Miller and Singh 1995) for the North American margin has prompted a reexamination of the interpretations of Kay (1969) and Lefort (1973).

Kay (1969) noted the general northeasterly trend of the Canadian Appalachian orogen and inferred its continuity northeastward onto, and across, the continental shelf northeast of Newfoundland from the sparse geophysical data available to him. He also inferred the southwestward continuation of the Caledonides across the European shelf. These observations led him to suggest an offset of these belts across the Atlantic and to speculate that this offset was the result of significant rightlateral movement on a NW-oriented Biscay-Labrador fault zone. The modern interpretation (Lefort 1989), based on more extensive marine geophysical data, does not require the offset suggested by Kay (1969). Instead, a large structural bend represents the offshore extension of the indents and recesses characteristic of this belt, as previously observed onshore (Rankin 1976). The shearing effect inferred by Kay (1969) to be associated with the dextral offset has been reconfirmed, but the fault zone is wider and the displacement along it less.

The objective of this paper is to document where the NWoriented faults and lineations have been mapped in western Europe and eastern Canada. We present evidence that the features may have been formed as a result of the collision between Gondwana and Laurasia in the late Paleozoic (which apparently represents the latest major compressional event in the area). The general geometry of such a collision is compared with the result of a sandbox model.

\section{DATA SETS}

The European data used in this paper have been compiled from numerous publications over the past thirty years, in which the authors interpreted the presence of features trending NW-SE from a variety of data sets. The inferred features are generally interpreted in publications as fault zones along which there has been dextral movement. The European data set thus represents a second-order data set.

The Canadian data for the Grand Banks consist of the directional arrows calculated by Miller and Singh (1994) from gravity and magnetic data, which had been interpolated on to a grid having a $5 \mathrm{~km}$ spacing. The computation details are available in Miller and Singh (1994). Only the arrows having a NW orientation (azimuth between $292.5^{\circ}$ and $337.5^{\circ}$ ) are presented here (Fig. 1). Miller and Singh (1995) further identified several major lineations oriented NW-SE based on aggregation patterns for the directional arrows. The arrows then are primary data, and the inferred lineations are a secondorder set comparable to the European data set. The Canadian data for the Scotian Shelf and on land are extracted from published sources and are similar to the European data set.

The two data sets are considered of equal validity. The published European and on-land Canadian data are based on mapping undertaken by their primary reference authors and include lineations inferred from satellite data; the geophysical data, from which the Grand Banks lineations are inferred, were extracted from the existing, publicly released data sets subjected to a well-documented process (Miller and Singh 1994). The seismic data have been processed and interpreted by Welsink et al. (1988). Some variance exists in the interpretation of the age of some of the features on the Grand Banks; Miller and Singh (1995) presented an argument for an age predating the present opening, whereas Welsink et al. (1988) and Miller (1990) presented another argument for a Mesozoic age. Williams et al. (1995) presented an argument for Mesozoic age for similar features on land throughout eastern Canada. The present paper addresses the reactivation of older structures during the opening of the present Atlantic Ocean.

In general, the presence of numerous, short, closely spaced features is the same on both sides of the Atlantic Ocean. The short and discontinuous features generally have not been represented by most European authors, who have presented only the aggregate, or major zones, similar to these on the Canadian side (Miller and Singh 1995).

The data for the study area are presented in a Mercator projection (Fig. 1) to preserve the true azimuth of the cited structures, although with some distortion of distance inherent in a Mercator projection. This projection is the only one on which to confirm whether the European and North American lineaments are comparable in direction. For Fig. 1, the fit of the continents is based on the correlation of the late Variscan structures on both sides of the North Atlantic, using rotation poles from Lefort (1989) rather than on the oceanic magnetic lineations (Srivastava and Verhoef 1992). In this presentation the Bay of Biscay between Spain and France has also been closed. The fit of Lefort (1989) has been chosen, as our objective is to examine the correlation between features which are interpreted to have arisen as a result of a pre-Mesozoic event, and hence the placement of the continents to assess the correlation is one which is relevant for that time period.

\section{EVIDENCE FOR NW-TRENDING FEATURES}

\section{I - Europe}

\section{Western France and southwestern England}

The first reference to NW-trending faults in Europe was made by Dearman (1963) who, using the Devonian Bodminmoor and Dartmoor granites as markers, calculated that the Cornubian peninsula of SW England (1, Fig. 1) has undergone right lateral displacement of approximately $34 \mathrm{~km}$. $\mathrm{He}$ also demonstrated one of the fundamental characteristics of this belt of NW-SE faults that has since been observed elsewhere, namely that although each fault is responsible for a small lateral offset, the cumulative displacement can be large due to the presence of numerous closely spaced faults. The fault set was considered to have been Tertiary in age because 


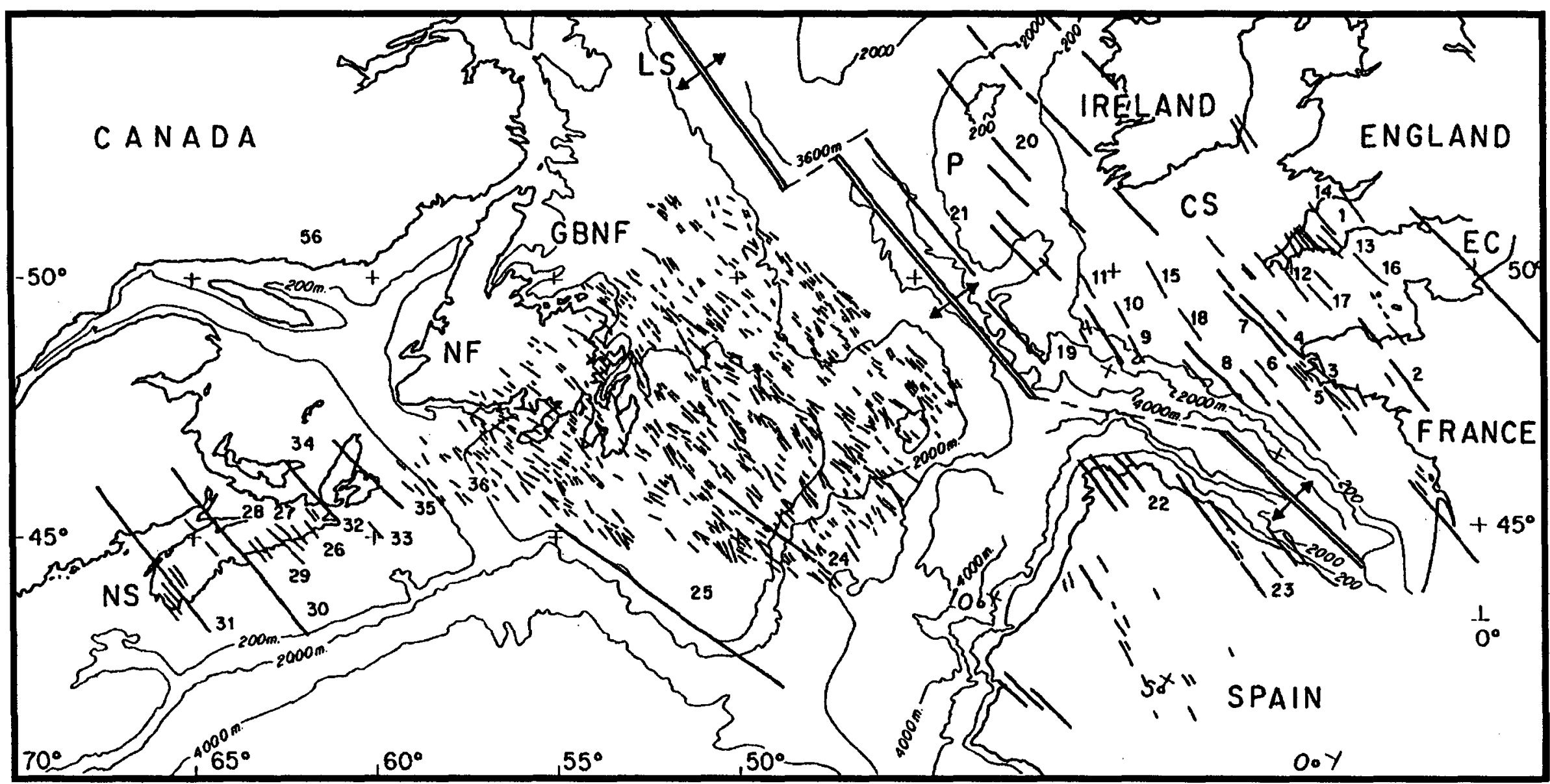

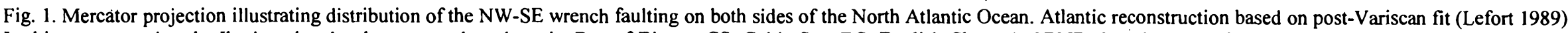

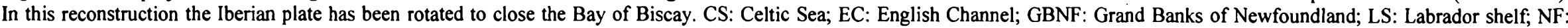

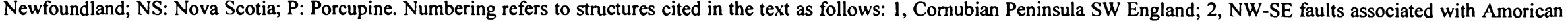

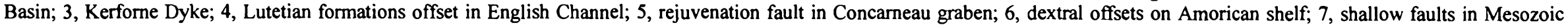

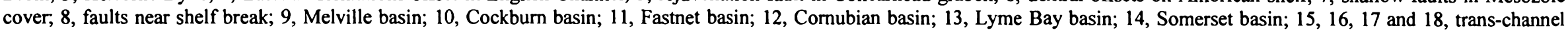

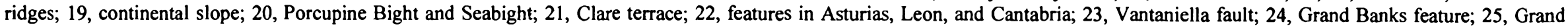

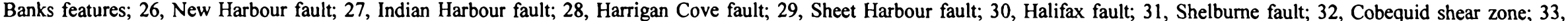
Euridice fault; 34, 35, and 36, Collector anomaly-related features. 
it cut across Devonian granite and was also interpreted to control the emplacement of the Bovey Tracey graben, a Tertiary feature.

Across the Channel in Brittany, Jeager (1967) also noticed that small Tertiary basins of the Armorican Massif are aligned along a major fault system trending NW-SE (2, Fig. 1) parallel to the doleritic Kerforne dyke (3, Fig. 1). The original Kerforne fault offsets the late Hercynian South Armorican shear zone. The fault was intruded by the dolerite around 190$205 \mathrm{Ma}$ (Leutwein et al. 1972). Thus, the age of the fault is between $295 \mathrm{Ma}$, the age of the shear zone, and $190 \mathrm{Ma}$, the age of the dolerite, implying that it is probably younger than the latest Variscan deformation and older than the TriassicJurassic boundary. A Permo-Triassic age is suggested. The offshore extension of this fault affected the Lutetian formations of the English Channel (4, Fig. 1) and controlled deposition of Miocene sediments in the Ouessant graben (Andreiff et al. 1973). The same fault is interpreted to be responsible for a similar succession of rejuvenation in the Concarneau graben (5, Fig. 1) on the Bay of Biscay shelf (Audren and Lefort 1977).

The gravity and magnetic map of the English Channel, west of Brittany and north of the Bay of Biscay, reveals that many mafic bodies on the Armorican shelf (Lefort 1975) are characterized by dextral offsets (6, Fig. 1). Where these offsets have been delineated, the Mesozoic cover is cut by NW-SE faults imaged in shallow seismic reflection studies (Lefort 1975) (7, Fig. 1). Detailed oil industry surveys northwest of Brittany show that the NW-oriented faults are widespread (Richert and Bodou 1977), and that this fault direction commonly interrupts the cover up to the Miocene in areas close to the shelf break (8, Fig. 1). Some company interpretations (unpublished BP internal report) suggest that the formation of the Melville (9, Fig. 1), Cockburn (10, Fig. 1), Fastnet (11, Fig. 1), Cornubian (12, Fig. 1), Lyme Bay (13, Fig. 1) and Somerset (14, Fig. 1) basins resulted from pullapart openings along NW-SE faults during the Lower Permian.

Similar seismic survey data show that trans-Channel basement ridges are oriented NW-SE $(15,16,17$, and 18, Fig. 1). Observations from the English Channel (Boillot and Lefort 1974) and Bay of Biscay (Boillot and Lefort 1976) have been incorporated into Fig. 1.

Westward, close to the Irish shelf break, other detailed seismic studies show that the NW-SE fault system controlled the location of the continental slope and the geometry of some of the bordering tilted blocks (Guennoc 1978) (19, Fig. 1).

\section{West of Ireland}

Magnetic maps (Lefort and Max 1984) and gravity maps (Masson and Miles 1986) for Porcupine Bank and Seabight reveal the existence of clear linear features oriented NW-SE (20, Fig. 1). The most prominent coincides with faults controlling the shape of the Clare Terrace (21, Fig. 1), which is the boundary between the continental and oceanic crust (Lefort and Max 1984, Masson and Miles 1986). This contact shows that the NW-SE faults are at least as old as the North Atlantic opening in this area.

\section{North of Spain}

When Spain is properly rotated (Lefort 1989) to close the Bay of Biscay and restore the Iberian plate to its original position (Fig. 1), many linear shear zones in the Precambrian and the Paleozoic basement of Asturias, Leon and Cantabria (22, Fig. 1) become parallel to the NW-SE fault set recognized west of France and Ireland (Parga 1969). The Ventaniella fault (23, Fig. 1) has been studied in detail (Julivert et al. 1971) because it was considered to have been a transform direction for the opening of the Bay of Biscay. Field evidence shows that this fault, which is responsible for a dextral offset of 4 to 5 kilometres, is almost certainly Permian in age. The other faults with similar trends are considered the same age as the Kerforne fault described earlier. North of Spain these faults were reactivated during the Tertiary (Pello 1967). Additional unnumbered NW-trending faults represented on Fig. 1 are taken from linears on an air photo interpretation of Spain (Tamain 1975).

\section{European data summary}

The western margin of Europe is characterized by a set of NW-SE faults both onshore and offshore. These faults, which cut across Variscan structures, form a linear belt that acted as a dextral shear zone. This shear zone can be dated as Permian where it is not buried beneath Mesozoic or Cenozoic sediments (Richert and Bodou 1977). During the opening of the North Atlantic Ocean, this belt experienced an east-west extensional regime (Richert and Bodou 1977), and formed many of the buried Triassic-Jurassic grabens and some the doleritic intrusions. Subsequent extension during the Tertiary reactivated these structures.

\section{II - Eastern Canada}

\section{The Grand Banks of Newfoundland}

On the Grand Banks of Newfoundland, Welsink et al. (1988) identified two short transverse lineaments linking the Mesozoic and Cenozoic basins in the Flemish Pass. These lineaments were interpreted to be Mesozoic or younger transfer faults (Tankard and Welsink 1987; Enachescu 1987). Only one of them shows a true NW-SE direction (24, Fig. 1). Welsink et al. (1988) and Miller (1990) visually identified some weak trends having a similar direction on the gravity and magnetic maps. A less subjective approach has been applied to the gravity and magnetic data (Miller and Singh 1994, 1995). The full set of NW-SE arrows calculated by these authors is reproduced in Fig. 1. Two of their inferred major lineations (SE $5 \&$ SE 8) are shown in Fig. 2. The Newfoundland fracture zone, which acted as a major transform at the continental margin during the opening of the North Atlantic in the Mesozoic (Keen et al. 1990), is approximately parallel to the NW-SE set of the Banks (25, Fig. 1). It represents a major boundary between continental crust of the Grand Banks and the oceanic crust.

The Miller and Singh (1995) analysis concentrated on the entire Grand Banks and the adjoining region of Newfoundland, whereas the Welsink et al. (1988) analysis focused on the eastern Grand Banks. Hence, there are subtle differences in the inferred features interpreted by the two studies. Welsink et al. (1988) noted that the fault zones consist 


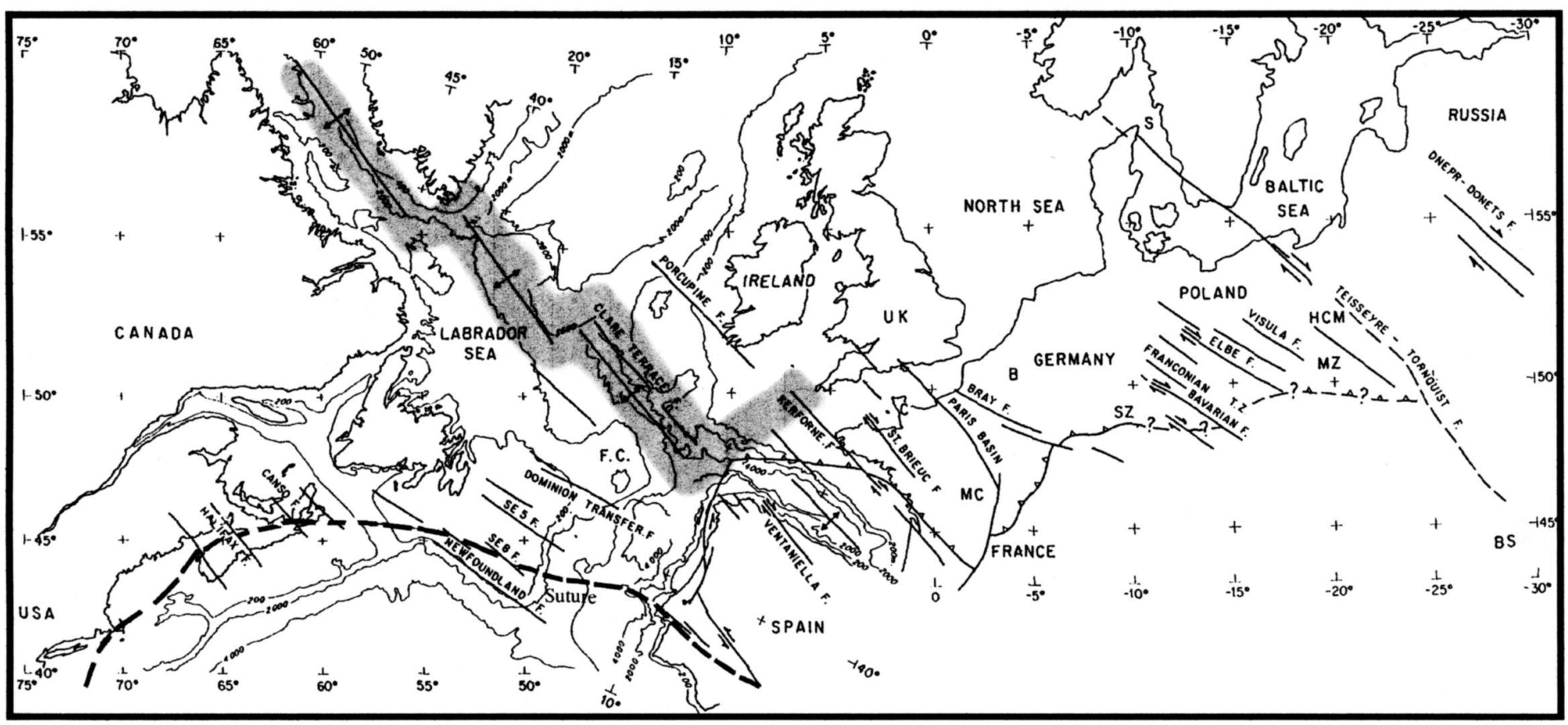

Fig. 2. Same Mercator projection base map as Fig. 1 to illustrate lateral extent of the NW-SE Wrench faulting. B: Brabant; BS: Black Sea; C: Cotentin; FC: Flemish Cap; HCM: Holly Cross Mountains; MC: Massif Central; MZ: Moldanubian Zone: S: Skagerrak; SZ: Saxothuringian Zone. Heavy dashed line represents locus of Gondwana-Laurasia suture in Iberia and North America. 
of en echelon disruptions similar to those onshore in Europe. This correlation suggests that the aggregations of trends such as SE 1-10 (Miller and Singh 1995) and the NW-trending features (Miller 1990) are similar fault zones. These features are most likely part of the basement, as the overlying sedimentary rocks, which constitute the cover, generally have very weak magnetic susceptibilities. Their gravity effects are related to disruptions in significant positive gravity anomalies caused by offsets in the denser basement.

\section{The Island of Newfoundland}

The general geological trend in Newfoundland is northeasterly, consistent with the general trend of the Appalachian orogen. Some authors have noted the presence of NW-trending faults and lineations orthogonal to the general trend, and the presence of east-west lineations (Miller 1990). McCartney (1969) discussed the presence of NW-trending tear faults on the Avalon Peninsula which were considered to have been post-Precambrian in age. Miller $(1987,1988)$ investigated trends immediately offshore, which continue onshore through the Avalon Peninsula, and concluded that these NW-oriented faults are probably Carboniferous. Riveros et al. (1994) further studied these features and confirmed a relatively young age. Furthermore, two of the lineations offset the Dover Fault, which is the boundary between the Gander and Avalon terranes in Newfoundland. The latest movement on the Dover Fault is considered Devonian to Carboniferous, and hence the age of the NW-trending faults is inferred to be younger (Miller 1990; Williams et al. 1995). Features of similar age and orientation have been mapped geophysically in a Carboniferous basin in western Newfoundland (Miller $e t$ al. 1990), together with east-west features. Williams et al. (1995) also noted the presence of NW-SE features elsewhere in Newfoundland.

\section{Nova Scotia}

In Nova Scotia and on the Scotian shelf, Keppie (1982a,b) showed NW-trending faults such as the New Harbour Fault (26, Fig. 1), the Indian Harbour Fault (27, Fig. 1), the Harrigan Cove Fault (28, Fig. 1) and the Sheet Harbour Fault (29, Fig. 1), all of which cut across the Meguma Terrane. Many other short and unnamed structures of the same orientation have been identified on Landsat imagery (Keppie 1982a,b; Williams and Hy 1990; Williams et al. 1995). Two prominent features, the Halifax (30, Fig. 1) and Shelburne (31, Fig. 1) faults have been delineated using Landsat imagery (Keppie 1982a,b) and magnetic mapping (Miller 1990). These two features continue across the Scotian Shelf, Nova Scotia, and the Bay of Fundy into New Brunswick. The most interesting Landsat interpretation is in the St. Marys graben (Keppie 1982a,b), where NW-SE faults intersect the Cobequid shear zone (Eisbacher 1969), suggesting a post-Carboniferous age for the faults (32, Fig. 1). More recently, Webster et al. (1998) discussed the presence of NW-oriented structures in St. Marys basin. Offshore, seismic data support the existence of a postMesozoic dextral Euridice fault (33, Fig. 1) (Jansa et al. 1993) and a continuation seaward of the Canso disruption (32, Fig. 1) (Stockmal et al. 1990). Williams et al. (1995) documented the occurrence of features trending NW into New Brunswick. On a visual interpretation of the gravity and magnetic data for all of eastern Canada, Miller (1990) also identified a set of NW-trending features throughout the area, including Newfoundland, the Grand Banks, Nova Scotia and New Brunswick.

In general, a similar history of faulting can be inferred for both sides of the North Atlantic Ocean. In Canada, the field evidence indicates that the offset direction along the NW-SE faults varies along the Appalachian Orogen (Williams et al. 1995). Dextral offset is clear where faults trending NW intersect the Collector Anomaly (34, 35, and 36, Fig. 1) (Lefort and Ben Salmia 1992). This observation suggests that the offsets could be Triassic in age, because the last movements along the Collector Anomaly are considered Permo-Carboniferous in age based on geochronological data (Keppie and Dallmeyer 1987).

\section{Labrador - Bay of Biscay rift}

Lefort (1973) proposed that a late Paleozoic-early Mesozoic dextral shear belt developed before the LabradorBay of Biscay opening of the North Atlantic Ocean. Along the eastern Canadian margin, the North Atlantic opening occurred during the Triassic-early Jurassic off Nova Scotia and along the transform margin of the southern Grand Banks when Africa and America drifted apart (Keen et al. 1994). The margins east and north of the Grand Banks were formed during rifting between North America, Iberia and Europe in the early Cretaceous. The final rifting between North America and Greenland commenced in the earliest stages of the late Cretaceous.

Contemporaneous Triassic-early Cretaceous igneous rocks have been found on both the Grand Banks and west of Brittany. Keen et al. (1994) suggested that the opening between Europe and North America, and between North America and Greenland was controlled by plume tracks, as evidence for plume-related igneous rocks has been observed on the Labrador and Newfoundland shelves. The plume track they proposed follows a general NW-SE trend. They concluded, however, that plumes have not played a major role in the region. As we have presented evidence that the NWtrending features predated opening of the North Atlantic Ocean, there is no reason for the plume track to align with the pre-existing shear belt. The inferred plume track is defined partly by outcrops of Cretaceous rocks that are much younger than the Permo-Triassic shear belt.

Furthermore, it is not easy to understand why the opening of this branch of the North Atlantic Ocean would have been responsible for so large a shear belt. Therefore, it is useful to check whether there is a clear spatial relationship between the tectonic fault zone and the Labrador Sea - Bay of Biscay opening. The Labrador Sea - Bay of Biscay line is not continuous but is segmented in sections that do not align with one another. The palinspastic reconstruction of the Atlantic Ocean (Fig. 1) suggests an en echelon opening system, which further implies some rejuvenation of a pre-existing fault set rather than a simple, clearly defined rupture that separated the continents. 


\section{III - NW-trending features elsewhere in Europe}

\section{Western Europe}

Only the major features of this vast area will be discussed. East of Brittany, the Paris Basin magnetic anomaly (Fig. 2) is well known, but remains an enigma in spite of many geophysical studies (e.g., Autran et al. 1986) and borehole sampling (Burg et al. 1988). The basin is interpreted as a Paleozoic rift that closed during Variscan time. Its orientation and the presence of younger NW-trending faults in the nearby Cotentin (Vigneresse 1978), suggest rejuvenation by dextral faulting in Permo-Triassic time. Other dextral movements occurred later, as some are known in the Mesozoic (Richert and Bodou 1977). The Bray fault, interpreted on the basis of gravity data as the southern boundary of the Brabant Massif (Edel and Weber 1995), also experienced dextral movement around $320 \mathrm{Ma}$ (Matte et al. 1986), followed by subsequent Tertiary movement.

East of this zone, a prominent set of NW-SE dextral faults is known in Central Europe. This fault zone, which in places is observed in outcrop, has been extended beneath the cover using gravity data (Edel and Weber 1995). It is responsible for a systematic offset of Proterozoic rocks that constitute the basement of the Saxothuringian and Moldanubian terranes. In the West, the Franconian-Bavarian transfer zone (Fig. 2) is responsible for a dextral offset of $150 \mathrm{~km}$. It was initiated during late Variscan time (Weber and Vollbrecht 1989) and was rejuvenated during the Alpine orogeny. Some of these transcurrent faults were active during the PermoCarboniferous as they controlled the trend of the South German troughs (Weber and Vollbrecht 1989). Other fault zones in the East, such as the Elbe and Vistula faults, also exhibit dextral movement at the end of Variscan time. Because this fault set is in places associated with sinistral NE-trending shear zones, an indenting pattern has been locally envisaged. This model does not contradict our interpretation. Furthermore, it is not clear that the NE-trending sinistral faults were active at the same time as the NW-trending fault set.

The most spectacular shear zone in this part of the world is the buried Teisseyre-Tornquist long fault system (Fig. 2) between the Skagerrak and the Black Sea. The main branch links the Black and Baltic Seas and a minor branch veers westward toward Denmark (Pozaryski et al. 1982). The main branch corresponds to an old oceanic suture (the Tornquist sea of Barker and Gayer (1985)) or a transform fault which was active during middle and late Paleozoic time. Torsvik et al. (1990) considered that the convergence between Baltica and western Europe led to the development of a sinistral shearing system during the Permian. However, Lewandowski (1993), based on a detailed study in the Holly Cross Mountains (Fig. 2 ), which are very close to the Teisseyre-Tornquist zone, considered that the collision between Cadomia (or Armorica or Western Europe) and Baltica was responsible for main dextral strike-slip movement. The main shearing movement is dated from the Sudetian tectonic phase (330-320 Ma), which suggests that evolution of the strike-slip displacements between Eastern and Western Europe was diachronous. Dextral rejuvenations occurred in the late Carboniferous and Permian, at the end of the Triassic, and during the Cretaceous (Pozaryski et al. 1982).
All these data support the suggestion of Ziegler (1984) that a very wide dextral shear zone existed between Spain and Poland at the end of the Carboniferous or beginning of the Permian. The Mercator projection used in Fig. 1 and 2 eliminates confusion between the east-west faults of Northern Africa and Brittany and the NW-trending lineaments of Germany and Poland. An example of how the use of a questionable projection may lead to a different interpretation is the work of Arthaud and Matte (1975) who incorporated these two sets of faults in a general late Variscan wrench system between North America and Poland. The evidence that these two sets of lineaments cannot be part of the same fault system is given by the small circles of confidence for the common rotational pole based on the Bay of Biscay, Teisseyre-Tornquist and other NW-oriented faults (Lewandowski 1993). This is different from the rotational pole calculated for the E-W oriented faults of Western Europe and Northern Africa. In westernmost Europe, the field evidence also clearly indicates that the late Variscan E-W shear zones are cut by the NW-trending faults.

We note that the faults presented in our figures are a specific selection from the total set of faults in the area which have many directions and that other fault systems existed at the same time. We have undertaken a tentative study to determine if these other directions are compatible with our dextral NW-trending fault system, but we cannot make any firm conclusion because of the uncertainties in the age, or in the sense of shear, of these other faults. The only certain result is that the NW-SE dextral fault system postdated the generally NE (Caledonian-Appalachian) and the E-W (Variscan) trends and can be demonstrated, where good control exists, to predate the Triassic-Jurassic cover.

\section{FURTHER GEOGRAPHIC EXTENT OF THE NW-TRENDING FAULT SYSTEM}

Additional tentative correlations are presented here, as other interpretations and ages can be given to some of the features described below. Our purpose is to show that our model can be extended over a broad area in Europe.

Although the evolution of the Dnepr-Donets graben of Russia is now well understood (Stebova et al. 1995), the wrench history of faults that controlled this graben is poorly documented (Fig. 2). If Ziegler (1984) was correct, and these faults were dextral in latest Paleozoic time, they represent evidence of NW-trending structures as far east as the Ural Mountains.

In eastern Canada similarly oriented features extend into New Brunswick as suggested by the Halifax and Shelburne faults (Keppie 1982b) in Fig. 1 and from mapping by Williams et al. (1995). They may also extend to southern Quebec. In the eastern United States, there appear to be no features having this orientation (Klitgord et al. 1988).

This NW-trending fault system seems to be more or less limited by the northern boundary of Paleozoic Gondwana and does not extend far south of the Gondwanan suture. This is well defined by geological and geophysical data beneath the eastern United States and Canadian margins (in eastern Canada defined by the Bay of Fundy, the Cobequid Fault and the Collector Anomaly) (Lefort 1989). In western Europe the 


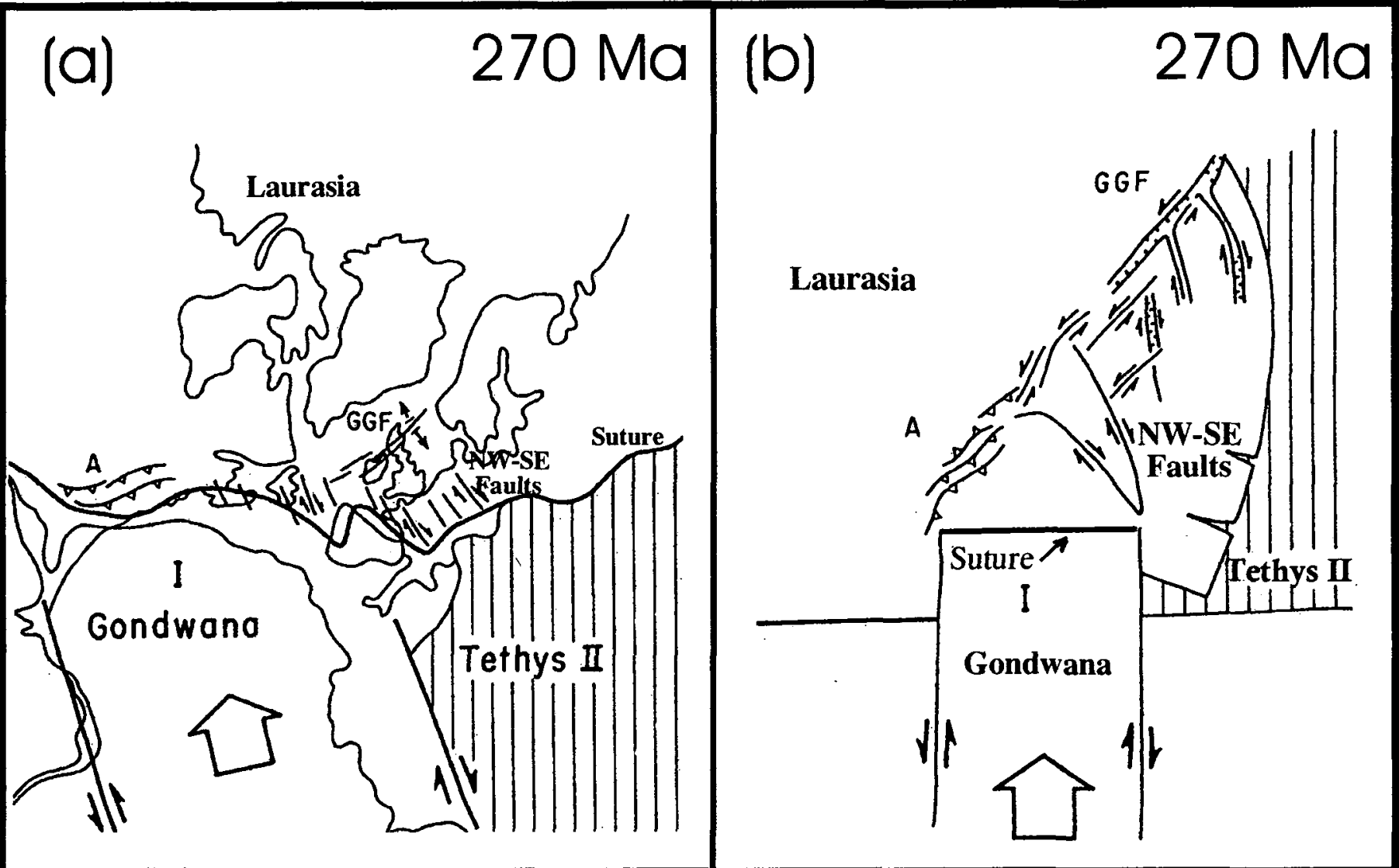

Fig. 3. (a) The collision between Gondwana and Laurasia (after Scotese et al. 1979). Thick solid line: suture zone; Vertical ruling: Tethys II ocean; A: Appalachians; GGF: Great Glen Fault System; I: Gondwana indenter. (b) Experimental indentation pattern in plasticine model with no lateral confinement (after Davy and Cobbold 1988). Same reference lettering as Fig. 3a. Thick solid line: suture zone; Vertical ruling: Tethys II ocean; A: Appalachians; GGF: Great Glen Fault System; I: Gondwana indenter.

eastward extension of this main boundary has been mapped using marine and onshore information up to the Massif Central (Lefort 1983). East of this area of accurate delineation, the suture is more difficult to follow because of Alpine deformation. On Fig. 2, we have reproduced the drawing of Franke (1989), which we consider the most appropriate to use between the Alps and the Teisseyre-Tornquist fault zone. Because of an apparent correlation between the location of the northern Gondwanan boundary and the southern limit of the NW-SE faulting, a short discussion on the late Paleozoic collision between Gondwana and Laurasia is necessary.

\section{The late Paleozoic Collision Between GONDWANA AND LAURASIA}

The collision between Gondwana and Laurasia is interpreted to have occurred in the late Carboniferous, giving rise to the Variscan Orogen (Scotese et al. 1979). A large shear zone developed at that time between the Urals and Spain (Ziegler 1984). Because of the change in stress orientation, two fault directions were formed. The first strike-slip movements developed along E-W transcurrent faults (Arthaud and Matte 1977) mainly during the Stephanian (latest Carboniferous). Fig. 2 presents the last wrench event, which occurred mainly in the Permian, and which is often confused with the previous one on other cartographic projections. Everywhere in Europe and in most locations in eastern Canada, where the two sets of faults exist, they clearly cut each other with the NW-trending system being the last one active. One exception is in New Brunswick (Williams et al. 1995) north of the location of the major boundary between Gondwana and Laurasia, which passes through the Bay of Fundy (Figs. 1 and 2).

It is particularly interesting to note that the NW-SE shear belt is not only located at, but also restricted to, the front of the collision between Gondwana and Laurasia (Fig. 3a). Just after Variscan shortening and the subsequent $\mathrm{E}-\mathrm{W}$ faulting, the following features were associated with the main collision zone (Fig. 3a):

1. The Tethys II ocean (Boulin 1981) was still open in the east.

2. NW-SE wrenching was developing, cutting across all the previous Variscan structures (Lefort 1973; Ziegler 1984).

3 . In the north, sinistral wrenching along the NE-trending Great Glen Fault of Scotland had just ceased (Kennedy 1946) but associated Permian dykes were intruding the Caledonian basement (Holgate 1969).

4. The Permian Southern Appalachian Mountains were building (Williams and Hatcher 1983).

These observed geological features are comparable with 
the pattern of deformation made by an indenter in a physical model experiment consisting of sand and plasticine with no confined lateral edge (Davy and Cobbold 1988). In our view, this model (Fig. 3b) replicates the effects of the post-Variscan collision because:

1. The open edge on the right is equivalent to the Tethys II Ocean.

2. Dextral strike-slip faults with a NW-SE orientation in front of the indenter are comparable with the location of similar features discussed in this paper.

3. On the top right, a now inactive sinistral strike-slip fault controlling a local extension is analogous to the Great Glen Fault as discussed above.

4. On the left, west-facing thrusts are equivalent to those in the southern Appalachian orogen.

\section{Conclusions}

The Biscay-Labrador fault zone corresponds to an old discontinuity that is part of a wide NW-oriented wrench zone located close to the initial Gondwana-Laurasia collision front. This wrench zone postdated the Variscan orogeny and resulted when Gondwana collided with and indented into Laurasia. The simultaneous thrusting, which affected the southern Appalachian orogen, and the extension that occurred close to the Great Glen fault can be explained by this indentation. The asymmetry of this process is a consequence of the free continental edge of Pangea, which was open toward the Tethys II Ocean. The rejuvenation of this zone during the opening of the North Atlantic in the Mesozoic affected the geometry of the shelves on both sides.

This conclusion is at variance with earlier interpretations for the source of the NW-oriented features on the North American side of the Atlantic. Various authors (Welsink et al. 1988; Miller 1990; Williams et al. 1995) have proposed that these features formed during the opening of the present Atlantic Ocean in the Mesozoic. Here, we interpret the North American evidence together with the European data to suggest that the features could have arisen earlier because of Gondwana-Laurasia collision in the late Paleozoic. The two interpretations are not as much at variance as it may appear. The North American authors concluded that the NW-trending features must have arisen after the closure of the Iapetus Ocean in the Devono-Carboniferous. The event they chose as a likely candidate for the origin of the NW-trending features was the opening of the Atlantic Ocean commencing in the Mesozoic. We have presented another possible scenario consistent with the geological and geophysical evidence known on both sides of the Atlantic Ocean. In our opinion, all the evidence for Mesozoic extension documented along this NW-SE belt provides an explanation for the width and length of the feature. The observed dextral offsets are evidence for the existence of a compressional regime, which is the only way to have formed the belt. In our view, the Mesozoic and Cenozoic structures are rejuvenated features.

\section{ACKNOWLEDGEMENTS}

The final manuscript benefited from the comments of the reviewers and the patient review of the editor and production manager.

\section{REFERENCES}

ANDReiff, P., Lefort, J.P., MARec, A., \& MonCiardini, C. 1973. Les terrains antécambriens et Paléozoïques au large du Leon, et leur relation avec la couverture secondaire et tertiaire de la Manche. Société géologique de Bretagne, C, 1, pp. 13-20.

ARTHAUD, F., \& MATTE, P.H. 1977. Late Paleozoic strike slip faulting in southern Europe and north Africa; result of a right lateral shear zone between the Appalachians and the Urals. Geological Society of America, Bulletin, 88, pp. 1305-1320.

AUDREN, C., \& LEFORT, J.P. 1977. Géologie du plateau continental sud armoricain entre les îles de Glenans et de Noirmoutier. Implications géodynamiques. Bulletin de la Société géologique de France, XIX, 2, pp. 395-404.

Autran, A., Castaing, C., Debeglia, N., Gulllen, A., \& Weber, C. 1986. Nouvelles contraintes géophysiques et géodynamiques pour l'interprétation de l'anomalie magnétique du Bassin de Paris. Hypothèse d'un rift paléozoïque referme au Carbonifêre. Bulletin de la Société géologique de France, 8, pp. 125-141.

BARKER, A.J., \& GAYER, R.A. 1985. Caledonides-Appalachian Tectonic analysis and evolution of related Oceans. In The tectonic evolution of the Caledonide-Appalachian orogen. F. Vieweg \& Sohn, pp. 125-165.

BOILLOT, G., \& LEFORT, J.P. 1974. Geological map of the English Channel. First edition, Bureau de Recherches Géologiques et Minières, 1 sheet.

BoIllot, G., \& LEFORT, J.P. 1976. Notice et carte géologique du plateau continental du Golfe de Gascogne. First edition, Bureau de Recherches Geologiques et Minières edit., 1 sheet.

Bouln, J. 1981. Afghanistan structure, greater India concept and Eastern Tethys evolution. Tectonophysics, 72, pp. 261-287.

Burg, J.P., Castaing, C.H., Chantraine, J., Hottin, A.M., KienaSt, J.R., Megnien, C., Turland, M., Vezat, R., \& WEBER, C. 1988. Les formations métamorphiques traversées par le sondage de Sancerre-Couy. Nouveau jalon de la chaîne varisque. Comptes Rendus de l'Académie des sciences Paris, 307, pp. 1819-1824.

DAVY, P., \& COBBOLD, P. 1988. Indentation tectonics in nature and experiment. 1. Experiments scaled for gravity. Bulletin of Geology of the University of Uppsala 14, pp. 129-141.

DEARMAN, W.R. 1963. Wrench faulting in Cornwall and south Devon. Proceedings of the Geological Association, 74, pp. 265287.

EDEL, J.B., \& WEBER, K. 1995. Cadomian terranes, wrench faulting and thrusting in the central Europe Variscides: geophysical and geological evidences. Geologische Rundschau, 84, pp. 412-432.

EISBASHER, G.H. 1969. Displacement and stress field along part of the Cobequid fault, Nova-Scotia. Canadian Journal of Earth Sciences, 6, pp. 1095-1104.

ENACHESCU, M.E. 1987. Extended basement beneath the intercratonic rifted basin of the Grand Banks of Newfoundland. International Conference on Basement Tectonics. 7th. (Kingston, Canada).

FRANKE, W. 1989. Tectonostratigraphic units in the Variscan belt. Geological Society, Memoir, 230, pp. 67-90.

GuENNOC, P. 1978. Structure et évolution géologique de la pente continentale d'un secteur de l'Atlantique Nord-Est de la terrasse de Meriadzec a l'éperon de Goban. Thesis, University of Brest, $110 \mathrm{p}$.

Holgate, N. 1969. Paleozoic and Tertiary transcurrent movements on the Great Glen Fault. Scottish Journal of Geology, 5, pp. 97139.

Jansa, L.F., Pe-PIPER, G., \& LONCAREvic, B.D. 1993. Appalachian basement and its intrusion by Cretaceous dykes, offshore southeast Nova-Scotia, Canada. Canadian Journal of Earth 
Sciences, 30, pp. 2495-2509.

JEAGER, J.L. 1967. Un alignement d'anomalies légères coïncidant avec des bassins tertiaires en Bretagne. Bureau de Recherches Géologiques et Minières Mémoire, 52, pp. 89-102.

JUliVERT, M., RAMIREZ DEL POZO, J., \& TRUYOLS, J. 1971. Le réseau de failles et la couverture posthercyniennedans la chaîne cantabrique. In Histoire structurale du Golfe de Gascogne, Publication de l'Institut français du Pétrole, 3, pp. 1-33.

KAY, M. 1969. Continental drift in North Atlantic. In North Atlantic Geology and Continental drift. Edited by M. Kay. American Association of Petroleum Geologists, Memoir 12, pp. 965-973.

KEEN, C.E., KAY, W.A., \& ROEST, W.R. 1990. Crustal anatomy of a transform continental margin. Tectonophysics, 173, pp. 527544.

KeEn, C.E., Courtney, R.C., Dehler, S.A., \& Williamson, M.C. 1994. Decompression melting at rifted margins: comparisons of model predictions with the distribution of igneous rocks on the eastern Canadian margin. Earth and Planetary Science Letters, 121, pp. 403-416.

KENNEDY, W.Q. 1946. The Great Glen Fault. Quarterly Journal of the Geological Society of London, CII, I, pp. 41-76.

KEPPIE, J.D. 1982a. Tectonic map of Nova-Scotia. Scale 1/500,000. Department of Mines and Energy Nova-Scotia. First edition.

KEPPIE, J.D. 1982b. Structural map of the Appalachian orogen in Canada. Scale 1/2000000, Memorial University of Newfoundland, First Edition.

KEPPIE, J.D., \& DALLMEYER, R.D. 1987. Dating transcurrent terrane accretion: an example from the Meguma and Avalon composite terranes in the northern Appalachians. Tectonics, 6, pp. 831847.

KLITGORD, K.D., HutChINSON, D.R., \& SchOUTEN, H. 1988. The Atlantic Continental Margin, US. Tectonic features and geophysical lineaments. D.N.A.G. Vol. I, 2. GNA-I2. Geological Society of America, 1 sheet.

LEFORT, J.P. 1973. La zonale Biscaye-Labrador: mise en évidence de cisaillements dextres antérieurs a l'ouverture de l'Atlantique Nord. Mar. Geol. M33-M38.

LEFORT, J.P. 1975. Le socle periarmoricain: Étude géologique et géophysique du socle submerge autour du Massif Armoricain. Thesis, University of Rennes, $250 \mathrm{p}$.

LEFORT, J.P. 1983. A new geophysical criterion to correlate the Acadian and Hercynian orogenies of Western Europe and Eastern America. In Contribution to the tectonics and geophysics of Mountain Chains. Edited by R.D. Hatcher, H. Williams, and I. Zietz. Geological Society of America, Memoir, 158, pp. 3-18.

LEFORT, J.P. 1989. Basement correlation across the North Atlantic. Springer-Verlag, $150 \mathrm{p}$

LEFORT, J.P., \& BEN SALMIA; A. 1992. Les accrétions laurentiennes et la propagation de l'effet de coin grenvillien. Comptes Rendus de l'Académie des sciences, Paris, 315, II, pp. 623-627.

LEFORT, J.P., \& MAX, M.D. 1984. Development of the Porcupine Seabight: use of magnetic data to show the direct relationship between early oceanic and continental structures. Journal of the Geologial Society of London, 141, pp. 663-674.

Le Pichon, X. Sibuet, J.C., \& FrancheTEaU, J. 1977. The fit of the continents around the North Atlantic Ocean. Tectonophysics, 38 , pp. 169-209.

LEUTWEIN, F. SONET, J., \& ZIMMERMAN, J.L. 1972. Dykes basiques du Massif Armoricain septentrional. Comptes Rendus de l'Académie des sciences, 275, pp. 1327-1330.

LEWANDOWSKI, M. 1993. Paleomagnetism of the Paleozoic rocks of Holly Cross Mountains (Central Poland) and the origin of the Variscan orogen. Publication of the Institute of geophysics of the Polish Academy of Sciences, A-23, 265, pp. 1-84.

MASSON, D.G., \& MILES, P.R. 1986. Structure and development of Porcupine Seabight. Sedimentary Basin, Offshore Southwest
Ireland. American Association of Petroleum Geologists, Bulletin, 70, pp. 536-548.

Matte, P., Respaut, J.P., Maluski, J., Lancelot, J., \& Brunel, M. 1986. La faille NO-SE du Pays de Bray: un décrochement ductile dextre hercynien, déformation a $320 \mathrm{Ma}$ dans le sondage Pays de Bray 201. Bulletin de la Société géologique de France, 8, II, pp. 55-69.

MCCARTNEY, W.D. 1969. Geology of the Avalon Peninsula, southeast Newfoundland. In North Atlantic Geology and Continental Drift. Edited by M Kay. American Association of Petroleum Geologists, Memoir 12, pp. 112-129.

MILLER, H.G. 1987. A geophysical interpretation of the onshore and offshore geology of the southern Avalon Terrane, Newfoundland. Canadian Journal of Earth Sciences, 24, pp. 60 69.

MILLER, H.G. 1988. Geophysical interpretation of the geology of the northeast Gander Terrane, Newfoundland. Canadian Journal of Earth Sciences, 25, pp. 1161-1174.

MILLER, H.G. 1990. A synthesis of the geophysical characteristics of terranes in eastern Canada. Tectonophysics, 177, pp. 171-191.

MILLER, H.G., \& SINGH, V. 1994. Semiquantitative techniques for identification and removal of directional trends in potential field data. Journal of Applied Geophysics, 32, pp. 199-121.

Miller, H.G., \& SINGH, V. 1995. The Avalon Terrane of Newfoundland: geophysical correlations from onshore to offshore as evidence for Precambrian to Tertiary structural evolution. Tectonophysics, 242, pp. 183- 197.

MILleR, H.G., KIlfoIl, G.J., \& PEAVY, S.T. 1990. An integrated geuphysical analysis of the Carboniferous Bay St. George Basin, western Newfoundland. Bulletin Canadian of Petroleum Geology, 38, pp. 320-331.

PARGA, J.R. 1969. Sistema de fracturas tardihercynicas del Macizo Hespérico. Trabajo del Laboratorio de Geología - University of Lage, 37, pp. 8-11.

Pello, J. 1967. Estudio geológico de la prolongación del borde oriental de la cuenca minera central de Asturias. Trabajo del Laboratorio de Geología de la Universidad de Oviedo, 1, pp. 27-38.

POZARYSKI, W., BROCHWICZ-LEWINSKY, W., \& TOMCZIK, H. 1982. Sur le caractère heterochronique de la ligne TeisseyreTornquist, entre Europe centrale et orientale. Comptes Rendus de l'Académie des sciences, Paris, 295, pp. 691-696.

RANKIN, D. 1976. Appalachian salients and recesses: Late Precambrian continental break-up and the opening of the Iapetus ocean. Journal of Geophysical Research, 81, pp. 5605-5619.

RICHERT, J.P., \& BODOU, P. 1977. Essai d'interprétation de la faille NO-SE du permis de Loire Atlantique. Internal Report, Elf Aquitaine Production, $12 \mathrm{p}$.

Reveros, C.P., Jamison, W.R., \& CAWOOD, P.A. 1994. Structural expression of the Avalonian and Acadian Orogenies in the Bacon Cove-Brigus area, Avalon Zone. Geological Association of Canada/Mineralogical Association of Canada Annual Meeting, Program with Abstracts, 19, p. A94.

SCOTESE, R.C., BAMBACH, R.K., BARTON, C., VAN DER VOO, R., \& ZIEGLER, A.M. 1979. Paleozoic base maps. Journal of Geology, 87, pp. 217-277.

SRIVASTAVA, S.P., \& VerhoEF, J. 1992. Basins on the Atlantic Saeboard: Petroleum Geology, Sedimentology and Basin evolution. Geological Society Special Publication, 62, pp. 397420.

Stobova, S., Stephenson, R., \& Dvorianin, E. 1995. DnieperDonets Basin, Ukraine: Main observations from regional seismic reflection profiles. Comptes Rendus de l'Académie des sciences Paris, 321 IIa, pp. 1103-1110.

Stockmal, G.S., Colman-Sadd, S.P., Keen, E.K., Marillier, F., O'BRIEN, S. J., \& QUINLAN, G.M. 1990. Deep structure and plate tectonic evolution of the Canadian Appalachians. Tectonics, 9, 
pp. 45-62.

TAMAIN, G. 1975. Megatectonique, linéaments et fracturation profonde de la Meseta Ibérique. Revue de Géographie Physique et de Géologie Dynamique, 17, pp. 375-391.

TANKARD, A.J., \& WELSINK, H.J. 1987. Extensional tectonics and stratigraphy of Hibernia Oil field, Grand Banks, Newfoundland, American Association of Petroleum Geologists, Bulletin, 71, pp. 1210-1232.

Torsvik, T.D., Smethurst, M.A., Briden, J.C., \& Sturt, B.A. 1990. A review of Paleozoic paleomagnetic data from Europe and their paleogeographical implications. Geological Society, Memoir, 12, pp. 25-41.

VIGNERESSE, J.L. 1978. Gravimétrie et granites armoricains. Thesis, Université de Rennes, $91 \mathrm{p}$.

Weber, K., \& Vollbrecht, A. 1989. The crustal structure at the KTB Drill site, Oberpfalz. In The German Continental Deep Drilling Program (KTB). Edited by R. Emmerman and J. Wohlenberg. pp. 5-36.

WEBSTER, T. L., MURPHY, J.B., \& BARR, S.M. 1998. Anatomy of a terrane boundary: an integrated structural, geographic information system, and remote sensing study of the late Paleozoic Avalon - Meguma terrane boundary, mainland Nova Scotia, Canada. Canadian Journal of Earth Sciences, 35, pp. 787-801.
Welsink, H.J., SRivastava, S.P., \& Tankard, A.J. 1988. Basin relationship of the Newfoundland continental margin and relationship with oceanic crust fabric during extension. In Tectonics and stratigraphy of the North Atlantic margin Edited by A.J. Tankard and H.R. Balkwill. 13, pp. 197-213.

WILLIAMS, H., \& HATCHER, R.D. 1983. Appalachian suspect terranes. Geological Society of America, Memoir, 158, pp. 33-53.

Williams, P.F., \& HY, C. 1990. Origin and deformation and metamorphic history of gold-bearing quartz veins on the Eastern Shore of Nova Scotia. In Mineral Deposit Studies in Nova Scotia, Volume I. Edited by A.L. Sangster. Geological Survey of Canada, Paper 90-8, pp. 169-194.

Williams, P.F., GoOdWIN, L.B., \& Lafrance, B. 1995. Brittle faulting in the Canadian Appalachians and interpretation of reflection seismic data. Journal of Structural Geology, 17, pp. 215-232.

ZIEGLER, P.A. 1984. Caledonian and Hercynian crustal consolidation of western and central Europe. A working hypothesis. Geologie en Mijnbouw, 16, pp. 93-108.

Editorial responsibility: Sandra M. Barr 